\title{
Pengaruh Pendapatan Asli Daerah, Dana Alokasi Umum dan Dana Alokasi Khusus Terhadap Belanja Modal di Kabupaten dan Kota Provinsi Jambi Tahun 2010-2018
}

\author{
Pantun Bukit, M Alhudhori \\ Fakultas Ekonomi Universitas Batanghari
}

\begin{abstract}
The aims of this research are to know: 1) The effect of Original Local Goverment Revenues to the Capital Expenditures in Special Region of Jambi Province. 2) The effect of General Allocation Funds to the Capital Expenditures in Special Region of Jambi Province. 3) The effect of Special Allocation Funds to the Capital Expenditures in Special Region of Jambi Province. 4) The effect of Original Local Goverment Revenues, General Allocation Funds and Special Allocation Funds simultaneously to the Capital Expenditures in Special Region of Jambi Province. The population in this research is regency and municipality in Special Region of Jambi Province. Data used comes from APBD Realization Report years 2010-2018. The technique of collecting data used documentation method. The test of prerequisite analysis used classical assumption test, those are normality, multicolinearity, heteroscedasticity and autocorrelation. The hypothesis test in this research used simple and multiple linear regression analysis. The results show that local revenue, general allocation funds, and profit sharing funds simultaneously affect capital expenditure where together these three variables have a $48 \%$ effect on capital expenditure, while partially local revenue has a positive and significant effect on spending. capital with a coefficient of 0.370 for general allocation funds also has a positive and significant effect on capital spending with a regression coefficient of 0.211 and profit-sharing funds partially also have a positive and significant effect on capital spending with a regression coefficient of 0.514 .
\end{abstract}

Keyword: regional income, allocation funds, capital expenditures

\section{PENDAHULUAN}

Dengan menurunnya penerimaan negara dari minyak dan pajak minyak sejak tahun 1983/84 dan berdampak pada menurunya anggaran pendapatan dan belanja negara tahun 1984/85 yang bersumber dari migas menyebabkan menurunnya kemampuan pemerintah pusat dalam memberikan subsidi kepada pemerintah daerah maupun dalam membiayai proyekproyek pemerintah di daerah. Untuk itu pemerintah pusat bertekad untuk memberikan kebebasan kepada pemerintah daerah dalam berusaha meningkatkan pendapatan asli daerah agar melemahnya subsidi dari pemerintah pusat tidak mengganggu perkembangan ekonomi maupun jalannya pemerintahan di daerah (Suparmoko, 2002)

Tekad pemerintah pusat untuk meningkatkan peranan pemerintah daerah dalam mengelola daerahnya sendiri dipertegas dengan lahirnya Undang-Undang otonomi daerah yang terdiri dari Undang-Undang Republik Indonesia No. 22 Tahun 1999 (direvisi menjadi Undang-Undang No. 23 Tahun 2014) tentang Pemerintahan Daerah dan Undang-Undang No. 25 Tahun 1999 (direvisi menjadi Undang-Undang Nomor 33 Tahun 2004) tentang Perimbangan Keuangan antara Pemerintah Pusat dan Pemerintahan Daerah. Adanya Undang-Undang otonomi daerah itu berarti bahwa ideologi politik dan struktur pemerintahan negara akan lebih bersifat desentralisasi dibanding dengan struktur pemerintahan sebelumnya yang bersifat sentralisasi. Dengan diberikannyaotonomi daerah setiap daerah diberikan kewenangan dan kewajiban untuk melaksanakan berbagai kegiatan pemerintahan secara lebih mandiri dan menggunakan sumber-sumber keuangan yang dimilikinya sesuai dengan kebutuhan dan aspirasi masyarakat.

Pemerintah daerah mengalokasikan dana dalam bentuk anggaran belanja modal. Menurut Direktorat Jenderal Perimbangan Keuangan (DJPK) belanja modal adalah pengeluaran anggaran untuk perolehan aset tetap dan aset lainnya yang memberi manfaat lebih dari satu periode akuntansi. Alokasi Belanja Modal ini didasarkan pada kebutuhan daerah akan sarana dan prasarana.Menurut Antari dan Sedana (2018) salah satu kegiatan belanja modal adalah pembangunan infrastruktur berupa fasilitas publik. Berkembang pesatnya pembangunan infrastruktur di suatu daerah mampu mendorong kegiatan investasi di daerah tersebut, sehingga berdampak terhadap pertumbuhan pendapatan daerah pada masa yang akan datang, perekonomian daerah yang semakin berkembang dapat menciptakan lapangan pekerjaan bagi masyarakat setempat.

Menurut Ekonom Institute for development of Economics and Finance (INDEF) Bhima Yudhistira mengungkapkan, percepatan realisasi belanja modal memang masih menjadi pekerjaan rumah pemerintah. Padahal, sebagian belanja modal dibiayai dari utang yang akan mubazir jika tidak terserap, beban bunga utang pemerintah terus meningkat. Salah satu cara untuk mendongkrak belanja modal adalah mempercepat pembangunan infrastruktur(Safyra Primadhyta, 2017).

Belanja modal adalah pengeluaran yang digunakan pengadaan atau pembangunan aset tetap berwujud yang nilai manfaatnya lebih dari setahun. Pembentukan aset tersebut meliputi pengadaan tanah, alat-alat berat, alatalat angkutan, alat-alat bengkel, alatalat pertanian, peralatan dan perlengkapan kantor, 
komputer, mebeulair, peralatan dapur, penghias ruangan, alat-alat studio, alat-alat komunikasi, alat-alat ukur, alatalat kedokteran, alat-alat laboratorium, konstruksi jalan, jembatan, jaringan air, penerangan jalan, taman dan hutan kota, instalasi listrik dan telepon, bangunan, buku/kepustakaan, barang seni, pengadaan hewan/ternak dan tanaman, serta persenjataan/ keamanan (Badan Pusat Statistik).

Pendapatan Asli Daerah (PAD) adalah pendapatan yang diperoleh daerah yang dipungut berdasarkan peraturan daerah sesuai dengan peraturan perundangundangan, guna keperluan daerah yang bersangkutan dalam membiayai kegiatannya. PAD terdiri atas pajak daerah, retribusi daerah, hasil perusahaan milik daerah dan pengelolaan kekayaan daerah yang dipisahkan, dan lain-lain pendapatan asli daerah yang sah (Badan Pusat Statistik)

Dana Alokasi Umum (DAU) adalah sejumlah dana yang harus dialokasikan pemerintah pusat kepada pemerintah daerah dengan tujuan pemerataan kemampuan keuangan antar daerah dan nilainnya minumum 25\% dari anggaran rutin dalam APBN.Dana ini dialokasikan $10 \%$ untuk provinsi dan $90 \%$ untuk Kabupaten/Kota Menurut (Suparmoko, 2002:42-43).

Dana Alokasi Khusus, selanjutnya disebut DAK, adalah dana perimbangan dan bersumber dari pendapatan APBN yang dialokasikan kepada daerah tertentu dengan tujuan untuk membantu mendanai kegiatan khusus yang merupakan urusan daerah dan sesuai dengan prioritas nasional

\section{Uji Asumsi Klasik \\ Uji normalitas}

Uji normalitas digunakan untuk melihat apakah variabel dependen dan independen berdistribusi normal atau tidak. Model regresi yang baik hendaknya berdistribusi normal. Untuk mendeteksi data berdistribusi normal atau tidak dapat diketauhui dengan menggambarkan penyebaran data melalui sebuah grafik.

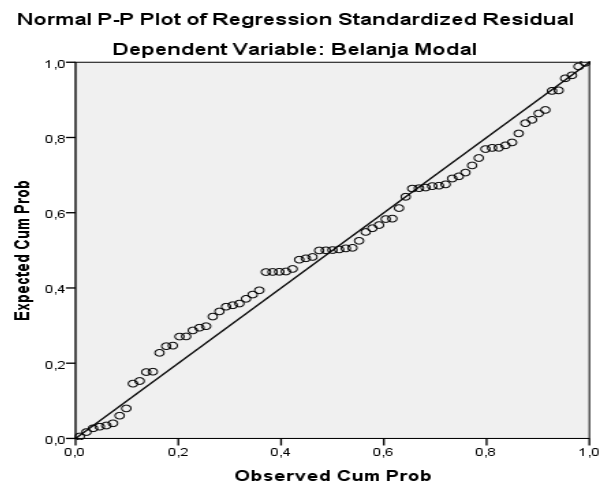

Gambar 1. Hasil Uji Normal Probability Plot

Berdasarkan tampilan output diatas kita dapat melihat bahwa titik-titik ploting yang terdapat pada gambar menyebar di sekitar garis diagonal dan mengikuti arah garis diagonal tersebut. Oleh karena itu, sebagaimana dasar pengambilan keputusan dalam uji normalitas teknik probability plot maka dapat disimpulkan bahwa model regresi memenuhi asumsi normalitas.

Uji kenormalan data juga dapat dilakukan dengan uji Kolmogorov-Smirnov. Suatu persamaan regresi berdistribusi normal apabila nilai signifikansi uji Kolmogorov Smirnov lebih dari 0,05. Adapun uji normalitas dengan uji one sample kolmogorov-Smirnov adalah sebagai berikut:

Tabel 1. Hasil Uji Normalitas Kolmogorov-Smirnov One-Sample Kolmogorov-Smirnov Test

\begin{tabular}{|ll|r|}
\hline & & $\begin{array}{c}\text { Unstandardized } \\
\text { Residual }\end{array}$ \\
\hline $\mathrm{N}$ & Mean & 77 \\
& Std. Deviation &,- 0000010 \\
Most Extreme Differences & Absolute & 028000 \\
& Positive &, 078 \\
Test Statistic & Negative &, 066 \\
Asymp. Sig. (2-tailed) & &,- 078 \\
& &, 078 \\
& &, $200^{\mathrm{c}, \mathrm{d}}$ \\
\hline
\end{tabular}

Berdasarkan tabel hasil otput SPSS diatas, diketahui bahwa nilai signifikansi Asiymp.Sig (2-tailed) sebesar 0,200 lebih besar dari 0,05. Maka sesuai dengan dasar pengambilan keputusan dalam uji normalitas Kolmogorov-smirnov di atas, dapat disimpulkan bahwa data berdistribusi normal, dan model regresi ini memenuhi uji normalitas.

\section{Uji Multikolineritas}

Uji multikolineritas bertujuan untuk mengetahui apakah pada model regresi ditemukan korelasi antarvariabel independen. Model regresi yang baik seharusnya tidak terjadi korelasi diantara variabel independen (bebas). Uji multikolineritas dilakukan dengan melihat nilai Tolerance dan Variance Inflation Factor (VIF). Jika nilai tolerance variabel independen $\geq$ 0,10 dan nilai VIF $\leq 10$ menunjukkan bahwa tidak adanya multikolinearitas antar variabel independen dalam model regresi. Berikut tabel hasil uji multikolineritas:

Tabel 2. Hasil Uji Mulikolineritas

\begin{tabular}{|ll|r|r|}
\hline \multirow{2}{*}{ Model } & & \multicolumn{2}{|c|}{ Collinearity Statistics } \\
\cline { 3 - 4 } & Tolerance & \multicolumn{1}{c|}{ VIF } \\
\hline 1 & (Constant) & & \\
& Pendapatan Asli Daerah &, 588 & 1,700 \\
& Dana Alokasi Umum &, 501 & 1,994 \\
& Dana Bagi Hasil &, 814 & 1,228 \\
\hline
\end{tabular}


Berdasarkan tabel diatas dapat dilihat bahwa nilai tolerance pendapatan asli daerah, dana alokasi umum dan dana bagi hasil $>0,10$, hal tersebut menunjukkan bahwa tidak ada korelasi antar variabel independen. Kemudian nilai Variance Inflation Factor (VIF) pendapatan asli daerah, dana alokasi umum dan dana bagi hasil adalah < 10. Jadi dapat disimpulkan bahwa tidak ada multikolineritas antar variabel independen dalam regresi.

\section{Uji Autokorelasi}

Uji autokorelasi dilakukan untuk mengetahui apakah dalam sebah model regresi linier terdapat hubungan yang kuat baik postif maupun negatif antardata yang ada pada variabel-variabel penelitian. Untuk mengetahui ada tidaknya autokorelasi dapat dilihat dengan nilai uji Durbin Watson (DW)

Tabel 3. Hasil Uji Autokorelasi

\begin{tabular}{|l|r|r|r|}
\hline Model & Durbin-Watson & $\mathrm{dL}$ & \multicolumn{1}{c|}{$\mathrm{dU}$} \\
\hline 1 & 1,801 & 1,5502 & 1,7117 \\
\hline
\end{tabular}

Dengan nilai tabel pada tingkat signifikansi 5\%, jumlah data $\mathrm{n}=77$ dan jumlah variabel independen $(\mathrm{k})$ dalam persamaan $=3$, maka didapatkan nilai batas bawah (dL) 1.5502 dan batas atas (dU) 1.7117. Karena nilai DW 1,801 lebih besar dari dU 1,7117 dan kurang dari (4-dU) 2,2883, maka dapat disimpulkan bahwa tidak terdapat autokorelasi pada model regresi ini.

\section{Uji Heteroskedastisitas}

Metode Grafik (Scatterplots)

Salah satu cara untuk mendeteksi adanya heteroskedastisitas adalah dengan melihat grafik plot antara nilai prediksi variabel terikat (ZPRED) dengan residualnya (SRESID) jika pola pada grafik berbentuk random atau acak, maka dikatakan persamaan regresi tidak terjadi masalah heteroskedastisitas. Hasil uji heteroskedastisitas dengan menggunakan metode grafik Scatterplots adalah sebagai berikut:

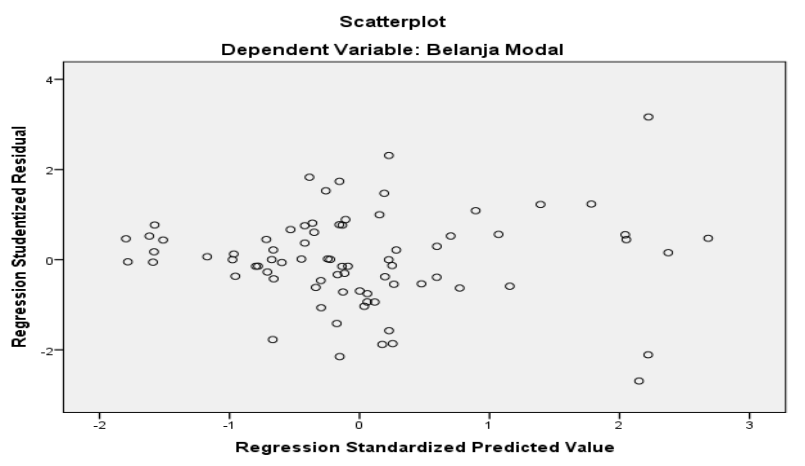

Gambar 2. Diagram Heteroskedastisitas

Pada gambar di atas terlihat bahwa titi-titik menyebar secara acak dan tidak membentuk pola tertentu, dan titik-titik menyebar di atas dan di bawah angka 0 pada sumbu $Y$. oleh karena itu, dapat disimpulkan bahwa tidak terjadi heteroskedastisitas dalam model regresi ini.

\section{Uji Koefisien Korelasi Spearman's Rho}

Cara mendeteksi heteroskedastisitas dengan uji Spearman Rho adalah jika nilai signifikansi (2-tailed) > 0,05 maka tidak terjadi masalah heteroskedastisitas. Jika nilai signifikansi (2-tailed) $<0,05$ maka terjadi masalah heteroskedastisitas. Hasil uji heteroskedastisitas dengan menggunakan uji Spearman's Rho adalah sebagai berikut:

Tabel 4. Hasil Uji Heteroskedastisitas dengan Uji Sperman's Rho Correlations

\begin{tabular}{|c|c|c|c|c|c|c|}
\hline & & & $\begin{array}{l}\text { Pendapatan } \\
\text { Asli Daerah }\end{array}$ & $\begin{array}{l}\text { Dana Alokasi } \\
\text { Umum }\end{array}$ & Dana Bagi Hasil & $\begin{array}{c}\text { Unstandardized } \\
\text { Residual }\end{array}$ \\
\hline \multirow{12}{*}{ Spearman's rho } & \multirow[t]{3}{*}{$\begin{array}{l}\text { Pendapatan } \\
\text { Asli Daerah }\end{array}$} & $\begin{array}{l}\text { Correlation } \\
\text { Coefficient }\end{array}$ & 1,000 &, $749^{* *}$ &,- 131 &,- 217 \\
\hline & & Sig. (2-tailed) & &, 000 & ,257 &, 058 \\
\hline & & $\mathrm{N}$ & 77 & 77 & 77 & 77 \\
\hline & \multirow{3}{*}{$\begin{array}{l}\text { Dana } \\
\text { Alokasi } \\
\text { Umum }\end{array}$} & $\begin{array}{l}\text { Correlation } \\
\text { Coefficient }\end{array}$ & & 1,000 & & \\
\hline & & Sig. (2-tailed) & ,000 & & ,003 & ,691 \\
\hline & & $\mathrm{N}$ & 77 & 77 & 77 & 77 \\
\hline & \multirow[t]{3}{*}{$\begin{array}{l}\text { Dana Bagi } \\
\text { Hasil }\end{array}$} & $\begin{array}{l}\text { Correlation } \\
\text { Coefficient }\end{array}$ &,- 131 &,$- 333^{* *}$ & 1,000 &,- 030 \\
\hline & & Sig. (2-tailed) & ,257 & ,003 & & ,795 \\
\hline & & $\mathrm{N}$ & 77 & 77 & 77 & 77 \\
\hline & \multirow{3}{*}{$\begin{array}{l}\text { Unstandardi } \\
\text { zed } \\
\text { Residual }\end{array}$} & $\begin{array}{l}\text { Correlation } \\
\text { Coefficient }\end{array}$ &,- 217 &,- 046 &,- 030 & \multirow[t]{2}{*}{1,000} \\
\hline & & Sig. (2-tailed) &, 058 & 691 & ,795 & \\
\hline & & $\mathrm{N}$ & 77 & 77 & 77 & 77 \\
\hline
\end{tabular}


Dari tabel diatas dapat dilihat bahwa nilai sig. (2tailed) Pendapatan Asli Daerah adalah 0,058, Dana Alokasi Umum adalah 0,691 dan Dana Bagi Hasil adalah 0,795. Secara keseluruhan nilai sig. (2-tailed) > 0,05 maka dapat disimpulkan bahwa tidak terjadi masalah heteroskedastisitas dalam model regresi.

\section{Analisis Regresi Linier Berganda}

Metode analisis data dalam penelitian ini menggunakan model analisis regresi linier berganda dengan menggunakan data panel untuk melihat hubungan antara satu variabel dependen dengan lebih dari satu variabel independen dimana dalam penelitian ini mengukur pengaruh Pendapatan Asli Daerah (X1) Dana Alokasi Umum (X2) dan Dana Bagi Hasil (X3) terhadap Belanja Modal pada Kabupaten dan Kota di Provinsi Jambi. Hasil output analisis regresi linier berganda dengan menggunakan program IBM SPSS Statistics 22 dapat dilihat pada table dibawah ini:

Tabel 5. Hasil Analisis Regresi Linier Berganda Coefficients $^{\mathrm{a}}$

\begin{tabular}{|c|c|c|c|c|c|}
\hline \multirow[b]{2}{*}{ Model } & \multicolumn{2}{|c|}{ Unstandardized Coefficients } & $\begin{array}{l}\text { Standardized } \\
\text { Coefficients }\end{array}$ & \multirow[b]{2}{*}{$\mathrm{t}$} & \multirow[b]{2}{*}{ Sig. } \\
\hline & $\mathrm{B}$ & Std. Error & Beta & & \\
\hline 1 (Constant) & 35383480190,236 & 54992685708,193 & & ,643 &, 522 \\
\hline $\begin{array}{l}\text { Pendapatan } \\
\text { Asli Daerah }\end{array}$ &, 370 &, 145 & ,280 & 2,543 & ,013 \\
\hline $\begin{array}{l}\text { Dana Alokasi } \\
\text { Umum }\end{array}$ & ,211 &, 103 & ,245 & 2,055 & ,043 \\
\hline $\begin{array}{l}\text { Dana Bagi } \\
\text { Hasil }\end{array}$ &, 514 &, 073 & ,662 & 7,078 & ,000 \\
\hline
\end{tabular}

a. Dependent Variable: Belanja Modal

Berdasarkan tabel ringkasan hasil analisis regresi linier berganda diatas dapat diketahui bahwa nilai a (konstanta) adalah sebesar 35.383.480.190,236. Nilai b (koefisien regresi pendapatan asli daerah) sebesar 0,370. Nilai $b_{2}$ (koefisien regresi dana alokasi umum) adalah 0,211 dan nilai $b_{3}$ (koefisien regresi dana bagi hasil) adalah 0,514. Berdasarkan nilai $a, b_{1} b_{2}$ dan $b_{3}$ yang telah diperoleh berdasarkan tabel ringkasan hasil analisis regresi linear berganda, maka persamaan regresi linear berganda antara Pendapatan Asli Daerah $\left(X_{1}\right)$, Dana Alokasi Umum $\left(\mathrm{X}_{2}\right)$ dan Dana Bagi Hasil $\left(\mathrm{X}_{3}\right)$ sebagai variabel independen (bebas), terhadap Belanja Modal (Y) sebagai variabel dependen (terikat) dapat dinyatakan sebagai berikut:

$$
\begin{aligned}
& Y=35.383 .480 .190,236+0,370 X_{1}+0,211 X_{2}+0,514 \\
& X_{3}+e
\end{aligned}
$$

Persamaan regresi diatas dapat dijelaskan sebagai berikut:

a. Konstanta dari persamaan regresi sebesar 35.383.480.190,236 menyatakan bahwa jika nilai pendapatan asli daerah $\left(\mathrm{X}_{1}\right)$ dana alokasi umum (X2) dan dana bagi hasil (X3) adalah 0 , maka besarnya belanja modal tiap daerah sebesar 35.383.480.190,236.

b. Koefisien regresi pendapatan asli daerah sebesar 0,370 artinya jika pendapatan asli daerah mengalami kenaikan $1 \%$ maka belanja modal akan mengalami kenaikan sebesar $0,370 \%$ dengan asumsi variabel independen lainnya tetap. Koefisien bernilai positif artinya hubungan positif antara pendapatan asli daerah dengan belanja modal, semakin naik pendapatan asli daerah maka semakin naik pula belanja modal.

c. Koefisien regresi dana alokasi umum sebesar 0,211 artinya jika dana alokasi umum mengalami kenaikan $1 \%$ maka belanja modal akan mengalami kenaikan sebesar 0,211\% dengan asumsi variabel independen lainnya tetap. Koefisien regresi bernilai positif artinya hubungan positif antara dana alokasi umum dengan belanja modal, semakin naik dana alokasi umum maka semakin naik pula belanja modal.

d. Koefisien regresi dana bagi hasil sebesar 0,514 artinya jika dana bagi hasil mengalami kenaikan sebesar 1\% maka belanja modal akan mengalami kenaikan sebesar $0,514 \%$ dengan asumsi variabel independen lainnya tetap. Koefisien regresi bernilai positif artimya hubungan positif antara dana bagi hasil dengan belanja modal, semakin naik dana bagi hasil maka semakin naik pula belanja modal.

\section{Pengujian Hipotesis}

Uji F (Uji Secara Simultan)

Untuk menguji hipotesis yang pertama digunakan Uji F. Uji F ini dilakukan untuk mengetahui pengaruh semua variabel independen yang terdapat di dalam model secara bersama-sama (simultan) terhadap variabel independen. Dalam penelitian ini ingin melihat apakah variabel pendapatan asli daerah, dana alokasi umum, dan 
Pantun Bukit, Pengaruh Pendapatan Asli Daerah, Dana Alokasi Umum dan Dana Alokasi Khusus Terhadap Belanja Modal di Kabupaten dan Kota Provinsi Jambi Tahun 2010-2018

dana bagi hasil secara bersama-sama berpengaruh terhadap belanja modal. Untuk melihat apakah ada atau tidaknya pengaruh variabel independen terhadap variabel dependen, maka digunakan uji $\mathrm{F}$ dengan cara membandingkan nilai $F_{\text {hitung }}$ dengan $F_{\text {tabel }} . F_{\text {tabel }}$ dapat dihitung dengan menggunakan tingkat keyakinan 95\%, $\alpha$ $=5 \%$ atau 0,05 dengan menggunakan rumus $\mathrm{F}$ tabel $=(\mathrm{k}$ ; n-k). Dimana "k" adalah jumlah variabel independen sementara " $n$ " adalah jumlah data penelitian. Hasil output SPSS dapat dilihat pada tabel sebagai berikut :

Tabel 6. Hasil Uji F

$\mathrm{ANOVA}^{\mathrm{a}}$

\begin{tabular}{|lr|r|r|r|r|r|}
\hline \multicolumn{2}{|l|}{ Model } & Sum of Squares & Df & Mean Square & F & Sig. \\
\hline 1 & Regression & 298170929826533050 & & 993903099421776 & \multirow{2}{*}{22,469} &, $000^{\mathrm{b}}$ \\
& & 000000,000 & 3 & 80000000,000 & & \\
& Residual & 322915745254650200 & & 442350335965274 & & \\
& & 000000,000 & 73 & 2600000,000 & & \\
& Total & 621086675081183300 & & & & \\
& & 000000,000 & 76 & & & \\
\hline
\end{tabular}

Berdasarkan hasil output dari program SPSS diperoleh $F_{\text {hitung }}$ sebesar 22,469 dan $F_{\text {tabel }}$ sebesar 2,73 jika dibandingkan $F_{\text {hitung }}>F_{\text {tabel }}$ maka sebagaimana dasar pengambilan keputusan dalam uji $\mathrm{F}$ dapat disimpulkan bahwa $\mathrm{H}_{0}$ ditolak dan $\mathrm{H}_{\mathrm{a}}$ diterima, berarti pendapatan asli daerah, dana alokasi umum dan dana bagi hasil secara bersama-sama berpengaruh terhadap belanja modal.

\section{Uji t (Uji Secara Parsial)}

Uji $\mathrm{t}$ dilakukan untuk mengetahui pengaruh masing-masing variabel independen secara parsial terhadap variabel terikat. Dalam penelitian ini ingin melihat apakah variabel pendapatan asli daerah, dana alokasi umum, dan dana bagi hasil secara secara berpengaruh terhadap belanja modal. Untuk melihat apakah ada atau tidaknya pengaruh variabel independen terhadap variabel dependen, maka digunakan uji $\mathrm{t}$ dengan cara membandingkan nilai $t_{\text {hitung }}$ dengan $t_{\text {tabel. }} t_{\text {tabel }}$ dapat dihitung dengan rumus $t_{\text {tabel }}=(\alpha / 2 ; n-k-1)$. Hasil output SPSS dapat dilihat pada tabel sebagai berikut :

Tabel 7. Hasil Uji t

\begin{tabular}{|ll|r|r|}
\hline Model & & \multicolumn{1}{c|}{$\mathrm{t}$} & \multicolumn{1}{c|}{ Sig. } \\
\hline 1 & (Constant) &, 643 &, 522 \\
& Pendapatan Asli Daerah & 2,543 &, 013 \\
& Dana Alokasi Umum & 2,055 &, 043 \\
& Dana Bagi Hasil & 7,078 &, 000 \\
\hline
\end{tabular}

1) Uji Variabel $X_{1}$

Berdasarkan hasil output dari program SPSS diperoleh nilai $t_{\text {hitung }}$ pendapatan asli daerah sebesar 2,543 dan $t_{\text {tabel }}$ sebesar 1,993 jika dibandingkan nilai $t_{\text {hitung }}>t_{\text {tabel }}$ maka sebagaimana dasar pengambilan keputusan dalam uji $\mathrm{t}$ dapat disimpulakan bahwapendapatan asli daerah berpengaruh terhadap belanja modal.

2) Uji Variabel $X_{2}$

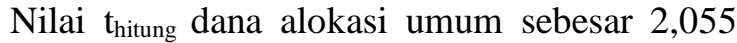
dan $t_{\text {tabel }}$ sebesar 1,993 jika dibandingkan nilai $t_{\text {hitung }}>$ $t_{\text {tabel }}$ maka sebagaimana dasar pengambilan keputusan dalam uji $t$ dapat disimpulkan bahwa dana alokasi umum berpengaruh terhadap belanja modal.

3) Uji Variabel $X_{3}$

Nilai thitung dana bagi hasil sebesar 7,078 dan $t_{\text {tabel }}$ sebesar 1,993 jika dibandingkan nilai $t_{\text {hitung }}>t_{\text {tabel }}$ maka sebagaimana dasar pengambilan keputusan dalam uji t dapat disimpulakan bahwadana bagi hasil berpengaruh terhadap belanja modal.

\section{Pengujian Koefisien Determinasi $\left(\mathbf{R}^{2}\right)$}

Koefisien determinasi $\left(\mathrm{R}^{2}\right)$ digunakan untuk mengetahui persentase sumbangan pengaruh secara bersama variabel-variabel bebas $(\mathrm{X})$ terhadap variabel terikat (Y). Koefisien determinasi $\left(\mathrm{R}_{\mathrm{y}(1,2,3)}^{2}\right)$ merupakan kuadrat dari koefisien korelasi $\left(\mathrm{R}_{\mathrm{y}(1,2,3))}\right.$.

Tabel 8. Hasil Uji Koefisien Determinasi Model Summary ${ }^{b}$

\begin{tabular}{|l|r|r|r|r|r|}
\hline Model & $\mathrm{R}$ & R Square & $\begin{array}{c}\text { Adjusted R } \\
\text { Square }\end{array}$ & $\begin{array}{c}\text { Std. Error of the } \\
\text { Estimate }\end{array}$ & Durbin-Watson \\
\hline 1 &, $693^{\mathrm{a}}$ &, 480 &, 459 & 66509423089,159 & 1,801 \\
\hline
\end{tabular}

a. Predictors: (Constant), Dana Bagi Hasil, Pendapatan Asli Daerah, Dana Alokasi Umum b. Dependent Variable: Belanja Modal

Berdasarkan tabel ringkasan hasil analisis regresi liner berganda nilai koefisen korelasi $\mathrm{R}_{\mathrm{y}}(1,2,3)$ adalah sebesar 0,693 kemudian besarnya koefisien determinasi $\left(\mathrm{R}_{\mathrm{y}(1,2,3)}\right)$ adalah 0,480 hal ini berarti kemampuan 
variabel independen dalam mendeskripsikan variabel dependen adalah sebesar $48 \%$ sedangkan sisanya 52\% dijelaskan oleh faktor-faktor lain diluar model.

\section{Pembahasan \\ Pengaruh Pendapatan Asli Daerah, Dana Alokasi Umum dan Dana Bagi Hasil Secara Simultan Terhadap Belanja Modal}

Hasil pengujian data dari tahun 2012 sampai dengan 2018 dengan menggunakan analisis regresi linier berganda menunjukkan bahwa pendapatan asli daerah (X1), dana alokasi umum (X2) dan dana bagi hasil (X3) secara bersama-sama berpengaruh terhadap belanja modal (Y). Hal tersebut ditunjukkan dengan nila $F_{\text {hitung }}$ 22,460 lebih besar dari $F_{\text {tabel }}$ 3,120 dan nilai koefisien determinasi $\left(\mathrm{R}^{2}\right)$ sebesar 0,480 menunjukkan bahwa kemampuan pendapatan asli daerah (X1), dana alokasi umum (X2) dan dana bagi hasil (X3) secara bersamasama dalam menjelaskan belanja modal (Y) adalah sebesar $48 \%$ sedangkan sisanya 52\% dipengaruhi oleh faktor-faktor lain di luar persamaan regresi berganda.

Hasil penelitian ini sejalan dengan penelitian yang dilakukan oleh Susanti \& Fahlevi (2016), Aditya \& Maryono (2018) dan Rifai (2019). Berdasarkan hasil penelitian Susanti \& Fahlevi (2016) yang berjudul "Pengaruh Pendapatan Asli Daerah, Dana Alokasi Umum, dan Dana Bagi Hasil terhadap Belanja Modal (Studi Pada Kabupaten/Kota di Wilayah Aceh)" menyatakan bahwaketiga variabel tersebut secara bersama-sama berpengaruh sebesar $80 \%$ terhadap belanja modal. Kemudian Penelitian Aditya \& Maryono (2018) yang berjudul "Pengaruh Pendapatan Asli Daerah, Dana Alokasi Umum, Dana Alokasi Khusus, Dana Bagi Hasil terhadap Belanja Modal (Studi Pada Provinsi/Wilayah Kalimantan dan Sulawesi" menyatakan bahwa keempat variabel tersebut secara bersama-sama berpengaruh sebesar $77,8 \%$ terhadap belanja modal. Berikutnya penelitian yang dilakukan oleh Rifai (2019) yang berjudul "Pengaruh Pendapatan Asli Daerah, Dana Alokasi Umum, Dana Alokasi Khusus, dan Dana Bagi Hasil terhadap Belanja Modal Pada Pemerintahan Daerah Kabupaten/Kota di Provinsi Sulawesi Tengah" menyatakan bahwa keempat variabel tersebut secara bersama-sama berpengaruh sebesar $52,1 \%$ terhadap belanja modal.

Pengaruh Pendapatan Asli Daerah, Dana Alokasi Umum dan Dana Bagi Hasil Secara Parsial Terhadap Belanja Modal

Pengaruh Pendapatan Asli Daerah terhadap Belanja Modal

Berdasarkan hasil penelitian diatas menunjukkan bahwa Pendapatan Asli Daerah (PAD) berpengaruh signifikan terhadap belanja modal pada Kabupaten dan Kota di Provinsi Jambi tahun 2012-2018. Hal ini di tunjukkan dengan nilai $t_{\text {hitung }} 2,543$ lebih besar dari $t_{\text {tabel }}$
1,993. Hasil ini menunjukkan bahwa semakin tinggi pendapatan asli daerah maka belanja modal akan semakin meningkat dan sebaliknya semakin rendah pendapatan asli daerah maka belanja modal akan semakin rendah.

Hasil penelitian ini sejalan dengan penelitian yang dilakukan oleh Suryana (2018) dan Susanti \& Fahlevi (2018) yang menyatakan bahwapendapatan asli daerah berpengaruh signifikan terhadap belanja modal. Namun hasil penelitian ini berlawanan dengan hasil penelitian dari Rifai (2019) yang menyatakan bahwa pendapatan asli daerah tidak berpengaruh signifikan terhadap belanja modal.

\section{Pengaruh Dana Alokasi Umum terhadap Belanja}

Berdasarkan hasil penelitian diatas menunjukkan bahwa Dana Alokasi Umum (DAU) berpengaruh signifikan terhadap belanja modal pada Kabupaten dan Kota di Provinsi Jambi tahun 2012-2018. Hal ini di tunjukkan dengan nilai $t_{\text {hitung }} 2,055$ lebih besar dari $t_{\text {tabel }}$ 1,993. Hasil ini menunjukkan bahwa semakin tinggi dana alokasi umum maka belanja modal akan semakin meningkat dan sebaliknya semakin rendah dana alokasi umum maka belanja modal akan semakin rendah. Hasil penelitian ini sejalan dengan penelitian yang dilakukan oleh Suryana (2018) dan Susanti \& Fahlevi (2018) menyatakan bahwadana alokasi umum berpengaruh signifikan terhadap belanja modal.Namun hasil penelitian ini berlawanan dengan hasil penelitian dari Rifai (2019) yang menyatakan bahwa dana alokasi umum tidak berpengaruh signifikan terhadap belanja modal.

\section{Pengaruh Dana Bagi Hasil terhadap Belanja Modal}

Berdasarkan hasil penelitian diatas menunjukkan bahwa Dana Bagi Hasil (DBH) berpengaruh signifikan terhadap belanja modal pada Kabupaten dan Kota di Provinsi Jambi tahun 2012-2018. Hal ini di tunjukkan dengan nilai $t_{\text {hitung }} 7,078$ lebih besar dari $t_{\text {tabel }} 1,993$. Hasil ini menunjukkan bahwa semakin tinggi dana abagi hasil maka belanja modal akan semakin meningkat dan sebaliknya semakin rendah dana bagi hasil maka belanja modal akan semakin rendah. oleh Suryana (2018) dan Susanti \& Fahlevi (2018) menyatakan bahwadana bagi hasi berpengaruh signifikan terhadap belanja modal.Namun hasil penelitian ini berlawanan dengan hasil penelitian dari Rifai (2019) yang menyatakan bahwa dana bagi hasil tidak berpengaruh signifikan terhadap belanja modal.

\section{SIMPULAN}

Berdasarkan hasil penelitian dan pembahasan yang telah dijelaskan pada bab IV, maka kesimpulan dari penelitian ini adalah:

1. Pendapatan Asli Daerah, Dana Alokasi Umum, dan Dana Bagi Hasil secara simultan berpengaruh 
terhadap Belanja Modal. Dimana secara bersamasama ketiga variabel tersebut berpengaruh sebesar $48 \%$ terhadap belanja modal

2. Pendapatan Asli Daerah, Dana Alokasi Umum, dan Dana Bagi Hasil secara parsial berpengaruh terhadap Belanja Modal (Y).

a. Pendapatan Asli Daerah (PAD) berpengaruh positif dan signifikan terhadap belanja modal pada Kabupaten dan Kota di Provinsi Jambi tahun 2012-2018 dengan koefisien regresi sebesar 0,370

b. Dana Alokasi Umum (DAU) berpengaruh positif dan signifikan terhadap belanja modal pada Kabupaten dan Kota di Provinsi Jambi tahun 2012-2018 dengan koefisien regresi sebesar 0,211

c. Dana Bagi Hasil (DBH) berpengaruh positif dan signifikan terhadap belanja modal pada Kabupaten dan Kota di Provinsi Jambi tahun 2012-2018 dengan koefisien regresi sebesar 0,514

\section{DAFTAR PUSTAKA}

Aditya \& Maryono (2018), Pengaruh Pendapatan Asli Daerah, Dana Alokasi Umum, Dana Alokasi Khusus, Dana Bagi Hasil terhadap Belanja Modal (Studi Pada Provinsi/Wilayah Kalimantan dan Sulawesi, Universitas Stikubank Semarang.

Andi Rosadi. (2012). Ekonometrika dan Analisis Runtun Waktu Terapan dengan Eviews. Yogyakarta: Andi Offset.

Antari \& Sedana (2018), Jurnal: Pengaruh Pendaptan Asli Daerah dan Belanja Modal Terhadap Kinerja Keuangan pemerintah Daerah, Vo. 7 No. 2, Jurnal Sumber: Manajemen, Universitas Udayana.

https://ojs.unud.ac.id/index.php/Manajemen/articl e/view/35806/22923

Armansyah (2019), Deskriptif Adalah, Sumber: https://rumus.co.id/deskriptif-adalah/\#menus.

Badrudin, Rudy (2012), Ekonomika Otonomi Daerah, Yogyakarta: UPP STIM YKPN

Hidayat (2012), Penjelasan Analisis Deskriptif \& Tutorialnya dengan Excel, Sumber:https://www.google.com/amp/s/www.stati skian.com/2012/10/analisis-deskriptif-denganexcel-html\%3famp

Hosana, Leica (2018), Pengaruh pendapatan Asli Daerah, Dana Alokasi Umum, Dana Alokasi Khusus, dan Surplus Anggaran Terhadap Belanja Modal (Studi Empiris Pada Kabupaten dan Kota Provinsi Jawa Barat), Universitas Pasundan Bandung.

Sumber:http://repository.unpas.ac.id/36995/.

Hidayat (2013), Uji F dan Uji T.

sumber:

https://www.google.com/amp/s/www.satiskian.co $\mathrm{m} / 2013 / 01 /$ uji-f-dan-uji-t.html\%3famp.

Hidayat (2013), Uji Heteroskedastisitas Spearman Rho. sumber:

https://www.satiskian.com/2013/01/ujiheteroskedastisita-spearman.html?amp-

Hidayat (2013), TutorialUji Heteroskedastisitas dengan Grafik Scatterplots SPSS

sumber:https://www.google.com/amp/s/www.satiskian.c om/2013/01/heteroskedastisitas-dengan grafik.html\%3famp.

Husein, U. (2008). Metode Penelitian untuk Skripsi dan Tesis Bisnis Edisi Kedua. Jakarta: PT RajaGrafindo Persada.

Khawarizmi (2011), Pendapatan Asli Daerah, Negara Hukum Sumber:http://www.negarahukum.com.

Kuncoro, M. (2014). Otonomi Daerah: Menuju Era Baru Pembangunan Daerah. Jakarta: Erlangga.

Mahmudi (2010), Manajemen Keuangan Daerah, Jakarta: Erlangga.

Permendagri Nomor 13 Tahun 2006 tentang Pedoman Pengelolaan Keuangan Daerah.

Peraturan Kementrian Keuangan (PMK) Nomor 127/PMK.02/2015 tentang Klasifikasi Anggaran.

Rasyid (2018), jurnal : Pengaruh Dana Alokasi Umum, Dana Alokasi Khusus, Dana Bagi Hasil dan Pendapatan Asli Daerah Terhadap Belanja Daerah Kabupaten/Kota Provinsi Sulawesi Tengah, Vol. 6 No, 1, Jurnal Katalogis, Universitas Tadulako.

Rifai (2019), jurnal :Pengaruh Pendapatan Asli Daerah, Dana Alokasi Umum, Dana Alokasi Khusus, dan Dana Bagi Hasil terhadap Belanja Modal Pada Pemerintahan Daerah Kabupaten/Kota di Provinsi Sulawesi Tengah, Vol. 5 No. 7, Jurnal Katalogis Universitas Tadulako.

Safyra Primadhyta(2017), Realisasi Belanja Modal Negara Naik 11 Persen Per Agustus.CNN Indonesia.

Sumber:https://m.cnnindonesia.com/ekonomi/20170918 084042-78242370/realisasi-belanja-modal-negaranaik-per-agustus.

Sudarmanto (2008), Analisis Regresi Linier Berganda dengan SPSS, Yogyakarta: GRAHAILMU.

Suharyadi et al (2018), Pengaruh Retribusi Daerah dan Hasil Pengelolaan Kekayaan Daerah yang Dipisahkan Terhadap Pendapatan Asli Daerah kabupaten Bogor, Vol. 5 No. 2, AMIK BSI bekasi.

Sumber:

http://ejoernal.bsi.ac.id/ejurnal/index.php/moneter.

Suparmoko, M. (2002).Ekonomi Publik Untuk Keuangan Dan Pembangunan Daerah.Yogyakarta: Andi Yogyakarta.

Suryana (2018), Jurnal: Pengaruh Pendapatan Asli Daerah (PAD), Dana Alokasi Umum (DAU), Dana Alokasi Khusus (DAK) Terhadap Belanja Modal.Vol 9 No 2, Jurnal Ilmu Manajemen dan Bisnis. 
Pantun Bukit, Pengaruh Pendapatan Asli Daerah, Dana Alokasi Umum dan Dana Alokasi Khusus Terhadap Belanja Modal di Kabupaten dan Kota Provinsi Jambi Tahun 2010-2018

Sumber:

https://ejournal.upi.edu/index.php/mdb/article/vie w/14000/8099.

Susanti \& Fahlevi (2016), Jurnal: Pengaruh Pendaptan Asli Daerah, Dana Alokasi Umum, dan Dana Bagi Hasil Terhadap Belanja Modal (Studi Pada Kabupaten/Kota di Wilayah Aceh), Vol. 1 No. 1, Jurnal Ilmiah Mahasiswa Ekonomi Akutansi (JIMEKA), Universitas Syiah Kuala.

Undang-Undang Republik Indoneisa Nomor 23 Tahun 2014 tentang Pemerintah Daerah

Undang-Undang Republik Indonesia Nomor 33 Tahun 2004 tentang Perimbangan Keuangan antara Pemerintah Pusat dan Pemerintah. 